縦断研究による、フローボリゥム曲線の個人間、 および個人内変動の推定

○中館俊夫、香川 順

（東女医大衛生・公衛）

目的：成人男性のフローボリウム曲線の縱断的な観 察によって、得られる指標の数年という時間尺度に おける個人間および個人内变動の大きさを推定し、 谜断研究と断面研究の検出力を比較する。

方法：おるに建材製品、工業製品を製造する2つの 事業場に勤務する $30 \sim 55$ 歳の男性 326 名に口 ーリングシール型スパイロメータを用いて最大努力 性呼出検査を行い、その $1 、 3 、 4$ 年後に同一の方 法で追跡調查を行った。退職者などを除いて 3 回以 上测定機会のあった 319 名のうち、3 回以上信頼 できる結果が得られた 269 名について、努力性肺

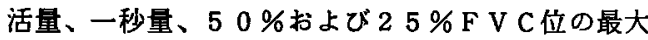
呼気流速の身長補正值（身長の 2 桃で除した值。C F V C 、C F E V1、C Vंmax $50 、 C \dot{V} \max 25$ と略）、 および通過時間の平均と標準偏差（M T T、S T T ） を、個人の肺機能レベルと年齿を説明変数とするモ デルによって解析した。

結果：対象者の、初回調查時の年龄、\% F V 、 F E V 1\%の平均はそれぞれ41.2歳、99.8\%、85.2\%、 現在喫煙者が64\%で、一般集団と大きく異なっては いないと考えられた。，指標の個人間変動と個 人内変動の大きさを比較すると、前者は後者の数倍 〜二十数倍の大きさで、とくに C F V C、C F E V 1 でその差が顕著であった。 6推定された変動の大 きさに基づいて、断面研究と縦断研究で必要となる 被検者数を算出すると、数倍〜二十数倍の違いがあ った。のまた同一の被検者を縦断的に観察する場 合と、断面的に観察する場合の検出力を、第 1 種の 過誤を $5 \%$ 、湘定值の $5 \%$ の変化を意味のある变化 として計算すると大きな違いが認められ、例えば F E V1では90\%の検出力を得るのに、緥断研究では 10 人程度でよいのに比べて断面研究では 200 人 程度を要し、また $\dot{V}$ max 25 では縦断研究では 200 人弱でよいのに対して断面研究では 1000 人以上 を要するという結果であった。

結論 : 本研究対象における肺機能指標の個人間、お よび個人内変動を比較すると、前者は後者の数倍〜 二十数倍あり、これに基づいて計算された検出力に あ同程度の大きな違いが認められた。今後重要にな ると考えられる低濃度慢性暴露の場合のような軽度 の影響の検出に、縦断研究が必要になると考えられ る。
砲金作業者の肺内ガス分布ーコンパートメン 卜解析法の応用

青野裕士（大分医大 公衛・衛生） 田吹光司郎 花輪四郎（大分労㗢管理 センター)

末梢肺領域におけるガス交換障害のひとつと して吸入気の並列的不均等分布に着目して、連 続呼吸法によるN2洗い出し曲線のマルチコン パートメント解析によりこの分布を数量化する とともに、銅、重鉛、錫を溶解し砲金製造する 作業者での応用例を報告する。

【方法および対象】

連続呼吸法によるN2洗い出し曲線は、開放 回路法を用い、被験者が安静な空気呼吸をした 後、純酸素呼吸に切り換え、一呼吸毎に呼気 N 2濃度を测定する。1. 肺の換気モデルは特定 の異なる換気率 (Si) N個のコンペートメ外で構成さ れるいとする。2.肺内ガス分布の同定：換気 率 Siを51個の定数で定める不均等分布曲線を 明かにするため、肺換気モデルと夷測檤の間の 残差平方和に平滑化項 $\left(\mathrm{Z} \cdot \mathrm{\Sigma}^{2} \mathrm{~V} \mathrm{i}^{2}\right)$ が付加さ れるが、Lewisらの係数Zを谷回はベイズ手法 を基礎とする赤池のベイズ型情報量規準 (ABIC )最小化で行う。3.三峰性の換気量分布曲線 の再現：Lewisが提示した三峰性の換気量分布 曲線から N 2洗い出し標準曲線を算出して、さ らに40個のガウスノイズ(平均 $\mu=0.0$ 標準偏 差 $\sigma=0.0125)$ をえ、再び51個の換気率での 換気量分布曲線を求める操作をした。4．砲金 作業者群 (男子26名) について瞕歴、居住歴、 既往歴呼吸器症状などの問診をおこない、年齢 をあわせた対照群（男子15名）の両者で安静 坐位の N2洗い出し検查を行い、呼気 N 2 漕度を ポリグラフ上に記録し、換気量分布曲線を求め た。また肺活量、努力性呼出曲線を測定した。 作業譩境調查は定期的になされ、最近は環境管 理Iであった。

【結果】三峰性のコンパートメント解析分布も 実際的なN2洗い出し曲線としてほほ正確に再 現できた。分布幅の如何にも係わらず再現は良 好であった。

砲金作業者群は対照群に比し明かな拘束およ び閉塞障害はなかったが、吸気量分画の換気率 の分散に有意差があった。

【考察】ベイズ変法により三峰性の換気量分布 曲線を再現できたことは実測されるN2清度值 に含まれる特性の違いや混入される測定誤差の 大小等の影響によらず肺内ガスの並列的な不均 等分布を視賞的に評価できると思われる。砲金 作業者群が対照群にくらべ吸入気分画の程度が より不揃いで肺内ガスの並列的な不均等分布が より多く見られた。しかしこの程度の並列的不 均等分布ではaADN2に影響するほどの拡散障害 はなく非顕性レベルであると考えられた。

1. Lewis, S. M. et al. J. Appl. Physiol. 42 (2) 1978. 
座長のまとめ $(734 \sim 738)$

\section{島 正吾（藤田保衛大医公衛）}

734 : B eに対する培盖細胞の感受性注、対象と した培美緗胞の種類によって異なり、また B eへの 感受性の差異は7 B e 取込み量にも影響されること

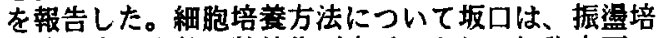
美法は生細胞数の数値化が容易であり、細胞表面へ のB eの接触が多い利点があるとした。

735 : 坂口らは、 $\mathrm{LD}_{5}$ 。相当のBe及びC Uのマ ウスー回投与において、6 週後のB e 投与群の $\mathrm{CH}_{50}$ 值、A C H 5 值、 $\mathrm{C}_{3}$ 量が、対照としたC 投与群とは異なった反応として認められるとした。 上記の $734 、 735$ は、坂口らの長期にわたる実 騦的研究の一罢としてあるものである。今後はこれ らの成果と、ヒトにおけるB e 障害発生との整合性 や、免疫毒性評価としての意義の解明を待ちたい。

736 : 太田らは、正常ラット脳における $\mathrm{Mn}$ SOD の分布について、形態的に㛟討した。太田 はさらに、檤内Mn-SODについての興味ある知

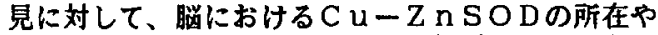
$\mathrm{Mn}$-SODの活性の程度、量の模討などは、今後 の課題としたいと述べた。本研究は独創性に富み、 その成果は注目すべきものがあり、さらなる研究の 発展を期待したい。

737 : 中馆らはフローホリリューム曲線について、 個人間及び個人内変動を模討し、こうした視点から、 低浱度慢性曝露による生体影響評価に対する䌊断的 研究の必要性を強調した。

738 : 青野らは、玸金作業者の瞄内ガス分右を検 討し、肺内ガスの亚列的な不均等分布の存在を指摘 した。本研究の成果についてヒトの呼吸機能、こと にいわゆるsmall air way に係わる影慗評価との関 連性、職場罯境污染要因との関連性など、活発な討 詳が行われた。

最後に今回のポスターセッションによる研究発表は、 多くの参加学会員によって、あらためて新鲜な感覚 で受けとめられたようであり、堀口学会長の卓見と ご盡力に敬意を表したい。
739

マウス末梢血に及活す三酸化アンチモンの影警

寺本敬子、脇谷扶美子、田中英徳

保津真一郎、堀口俊一(大阪市大医嚗境衛生)

（はじやに）アンチモン(3洒の化合物の場合)冲 吸収されると細胞内特に赤血球に分布すると言わ

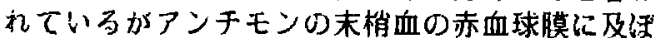
す影響に関する報告はない。今回はマウス赤血球 膜の浸透圧脆弱性におよ活す三酸化アンチモン $\left(\mathrm{Sb}_{\mathrm{c}} \mathrm{U}_{\mathrm{i}}\right)$ の急性影響に関寸为実験を行なった。

（方法）実駼 $1 ：$ ～過齡の I CRマウス120匹(体 重約30g)を 1 群30匹とし、4碰分分计た。1\%C $\mathrm{MC}$ 溶液に毷濁させた $\mathrm{Sb}_{2} \mathrm{O}$ : をマウス体重 $1 \mathrm{~kg}$ 卖たり、各群それそれ 0、0.2、1、5 g になるよ jに調整し、1 回経口投与した。投与 $1 、 3 、 10$ 日後に屠殺し、心操血を行なった。

実験 2：8週路の I C R マウス192匹(体重約35g) を 1 群48匹とし、4 群に分けた。実験 1 と同じ混 度の $S b_{\varepsilon} b_{3}$ 在経口投与した。投与注週3回（火、 木、土）、4週間計12回行い、投与開始後 $1 、 2$ 12 回後と投与終了後 $3 、 10 、 30$ 日後に屠殺し、心 㨲血を行なった。これらの血液についてCPC法 (Coil Planet Centrifuge System) により赫血球 膜浸透圧脆弱性を測定した。赤血球膜脆弱性流 血終了点 $(H E P)$ 、溶血開始点 (HSP)、溶血幅 （HW）て示した。また赤血球数（RBC）、血色素量 ( $\mathrm{H} \mathrm{b}$ ）、赤血球容積、白血球数 (WB C ) を測定し、 平均赤血球容䅧、平均赤血球血色素量、平均赤血 球血色素濃度を算定し、白血球分類を行なった。

(結果) 実験 1 では $\mathrm{Sb}_{2} \mathrm{O}_{3}$ の経口投与 1 日後、対 照群に比へて $5 \mathrm{~g} / \mathrm{kg}$ 投与群ではH E P、H S P值 ともに低值を示した。その他の項目については対 照群とほ汪同程度の值を示した。投与10日後は対 照群に比べて投与群ではH E P值が诚少した。血 液所見においては、投与群のRBC、H b ともに 対照群のそ机に比べて增加したが BCその他の 項目では变化は認められなかった。実験 2 では $\mathrm{Sb}_{2} \mathrm{O}_{2}$ の経口投与 3 回後、対照群に比へて $0.2 、$ $1 \mathrm{~g} / \mathrm{kg}$ 投与群で岋 H E P 值のみ減少傾向にあり、 投与 6 回後ではH E P、H S P 值ともに高值を示 した。投与12回後の1、3日後讨対照群とほ活同 し值を示したが、投与終了後10日目にはHEP、 H S P 値とむ沉低値を示す傾向か認めら机、30日 後に汹再じ同程度の值を示した。HWをの他の血 液所見に抏いて就照群とほほ同し値を示した。 （まとめ）今回の実験 1、2から得られた結果 $\mathrm{Sb}_{2} 0$ ：投与後10日目にHSPとHEPR共通の変

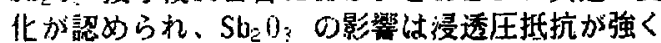
なるといわれている鉛と同様の傾向を認めたが、 その影霎程度は非常に小さいと考える。 